\title{
Modelling and Simulation of a Retail Commercial Refrigeration System
}

College of Science, School of Engineering, University of Lincoln, Brayford Pool, Lincoln LN6 7TS, UK. Emails: 14589728@students.lincoln.ac.uk (J. Noons), ialbayati@lincoln.ac.uk (I.M. Albayati).

*Corresponding Author

\section{Abstract}

Commercial food outlets in the UK are responsible for $3 \%$ of the UK total energy consumption, with refrigeration systems account for $29 \%$ of this total. This highlights the potential and importance of huge energy saving within commercial refrigeration systems. In this paper, a validated model that simulates a commercial refrigeration system installed over 2000 sqft to mimic a real express store installed at Riseholme Refrigeration Research Centre at the University of Lincoln, UK, is developed and presented. The detailed modelling of the display case using a temperature model comprising of three states include air inside the display case, products, and the evaporator. Additionally, the model presents a holistic view of the whole system with each subsystem cohesively linked together. Further focus has been given on the high temperature (HT) system due to the high level of installations of this system found in retail commercial refrigeration stores as well as low temperature (LT) systems featuring doors which decrease the heat transfer from the store into the cases. It is concluded that the trends of the simulation results for the display case temperatures, expansion valve opening degree, suction line pressures, and compressors power consumption, all have high resemblance to the trends of collected data obtained from Riseholme Refrigeration Research Centre. This supports the validation of the developed model.

Keywords: Modelling, Simulation, Commercial Refrigeration System, Compressor, Suction Line. 


\section{$27 \quad$ Nomenclature}

\begin{tabular}{|c|c|c|}
\hline Symbol & Parameter Description & Unit \\
\hline$C_{p, i}$ & Specific heat capacity, where $i$ denotes the media which the parameter refers to. & $\mathrm{J} / \mathrm{kg} \cdot{ }^{\circ} \mathrm{C}$ \\
\hline CPT & Calculated product temperature. & ${ }^{\circ} \mathrm{C}$ \\
\hline$C v$ & $\begin{array}{l}\text { Orifice coefficient or valve characterising constant - Collection of constants such as } \\
\text { the cross-sectional area of the valve inlet and outlet. }\end{array}$ & $\mathrm{m}^{3} / \mathrm{s}$ \\
\hline$h_{l g, \text { in }}$ & Enthalpy of the refrigerant at the inlet of the evaporator. & $\mathrm{J} / \mathrm{kg}$ \\
\hline$h_{l g, \text { out }}$ & Enthalpy of the refrigerant at the outlet of the evaporator. & $\mathrm{J} / \mathrm{kg}$ \\
\hline$k_{m}$ & $\begin{array}{l}\text { Ratio of mass of refrigerant in the evaporator to the maximum capacity of the } \\
\text { evaporator. }\end{array}$ & - \\
\hline$m_{i}$ & Mass, where $i$ denotes the media which the parameter refers to. & $\mathrm{Kg}$ \\
\hline$m_{\text {ref }}$ & Mass of liquefied refrigerant in the evaporator. & $\mathrm{Kg}$ \\
\hline$\dot{m}_{r e f, i n}$ & Mass flow rate of refrigerant into the evaporator. & $\mathrm{kg} / \mathrm{s}$ \\
\hline$m_{r e f, \max }$ & Maximum capacity of the evaporator. & $\mathrm{Kg}$ \\
\hline$\dot{m}_{\text {ref,out }}$ & Mass flow rate of refrigerant out of the evaporator. & $\mathrm{kg} / \mathrm{s}$ \\
\hline$\dot{m}_{\text {ref }, \text { out }, i}$ & Mass flow rate of the refrigerant leaving each of the display case's evaporator. & $\mathrm{kg} / \mathrm{s}$ \\
\hline$m_{\text {suc }}$ & Total mass of refrigerant in the suction line. & $\mathrm{Kg}$ \\
\hline$\dot{m}_{\text {suc,in }}$ & Mass flow rate into the suction line. & $\mathrm{kg} / \mathrm{s}$ \\
\hline$N_{\text {comp }}$ & Number of running compressors. & - \\
\hline$N_{D C}$ & Number of display cases in the system. & - \\
\hline$O D$ & Opening degree of the expansion valve. & - \\
\hline$P_{\text {rec }}$ & Pressure in the receiver. & $\mathrm{kPa}$ \\
\hline$P_{\text {suc }}$ & Pressure in the suction line. & $\mathrm{kPa}$ \\
\hline$\dot{Q}_{e}$ & $\begin{array}{l}\text { Heat transfer from the evaporator wall to the refrigerant in the evaporator. Also } \\
\text { termed to the cooling capacity. }\end{array}$ & $\mathrm{kW}$ \\
\hline$\dot{Q}_{\text {products }}$ & Heat transfer from the products to the air inside the display case. & $\mathrm{kW}$ \\
\hline$\dot{Q}_{\text {indoor }}$ & Heat load from the indoor supermarket temperature and local environment. & $\mathrm{kW}$ \\
\hline$t$ & Time & $\mathrm{s}$ \\
\hline$T_{\text {air-off }}$ & Temperature at the back of the display case. & ${ }^{\circ} \mathrm{C}$ \\
\hline$T_{\text {air-on }}$ & Temperature at the front of the display case. & ${ }^{\circ} \mathrm{C}$ \\
\hline
\end{tabular}




\begin{tabular}{|c|c|c|}
\hline$T_{e}$ & Evaporation temperature of the refrigerant in the evaporator. & ${ }^{\circ} \mathrm{C}$ \\
\hline$T_{\text {products }}$ & Temperature of the products in the display case. & ${ }^{\circ} \mathrm{C}$ \\
\hline$T_{\text {products,initia }}$ & Initial temperature of the products in the display case. & ${ }^{\circ} \mathrm{C}$ \\
\hline$T_{\text {indoor }}$ & Indoor temperature of the supermarket. & ${ }^{\circ} \mathrm{C}$ \\
\hline$T_{\text {shelf }}$ & Weighted combination of temperature probes in the display case. & ${ }^{\circ} \mathrm{C}$ \\
\hline$U A_{i}$ & $\begin{array}{l}\text { Overall heat transfer coefficient, where } i \text { denotes the media which heat is transferred } \\
\text { across. }\end{array}$ & $\mathrm{kW} / \mathrm{K}$ \\
\hline$\dot{V}_{\text {comp }}$ & Volumetric flow rate leaving the suction line. & $\mathrm{m}^{3} / \mathrm{s}$ \\
\hline$V_{\text {Evap, } \max }$ & Maximum volume of the evaporator. & $\mathrm{m}^{3}$ \\
\hline$\dot{V}_{d}$ & Maximum displacement volume rate of each compressor. & $\mathrm{m}^{3} / \mathrm{s}$ \\
\hline$V_{\text {suc }}$ & Volume of the suction line. & $\mathrm{m}^{3}$ \\
\hline$\dot{W}_{\text {comp }}$ & Power consumption of the compressor pack. & $\mathrm{kW}$ \\
\hline$\alpha$ & Empirical constant for display case probes. & - \\
\hline$\beta$ & Empirical constant for display case probes. & - \\
\hline$\eta_{v o l}$ & Clearance volumetric efficiency. & $\%$ \\
\hline$\rho_{\text {comp }}$ & Density of the refrigerant leaving the compressors. & $\mathrm{kg} / \mathrm{m}^{3}$ \\
\hline$\rho_{\text {liq, rec }}$ & Density of the liquid refrigerant passing through the expansion valve. & $\mathrm{kg} / \mathrm{m}^{3}$ \\
\hline$\rho_{\text {liq,suc }}$ & Density of the liquid refrigerant in the evaporator. & $\mathrm{kg} / \mathrm{m}^{3}$ \\
\hline$\rho_{\text {suc }}$ & Density of the suction line. & $\mathrm{kg} / \mathrm{m}^{3}$ \\
\hline
\end{tabular}

\section{1- Introduction}

30 The use of refrigeration systems in industries such as food production, pharmaceuticals and breweries 31 allowed for developments to be made in each respective field and are largely relied on daily operations. 32 The UK food and drink industry accounts for $£ 188$ billion of consumer expenditure and counts on 33 refrigeration systems for rapid cooling of meat, fruits, and vegetables to extend their product life and to 34 prevent the growth of harmful bacteria $[1,2]$. Refrigeration systems in the brewery industry are the largest single process consumers of electricity demanding $32 \%$ of the electricity provided to this sector

36 [3-5]. Pharmaceutical products require controlled cooling storages in order to maintain efficacy and their 37 safety $[6,7]$. 
The refrigeration systems for local food transportation are designed to operate dependably in severe environments in comparison to the domestic or commercial systems [8], resulting low operating efficiencies than that of stationary refrigeration systems [9]. Moreover, the increasing demand for transported refrigerated products has emphasised potential developments in order to reduce energy consumption and improving system performance. Refrigerated food transport in the UK is responsible for a $1.8 \%$ of emissions [10], while refrigeration systems for the international shipping transportation is responsible of emitting about $15 \mathrm{Mt} \mathrm{CO}_{2}$ [11]. Most transporter ships do not have the refrigerating capacity for fast cooling, so all products must be already pre-cooled prior to loading [12].

In commercial sectors, the improper cooling of food in restaurants and food outlets is a major cause of foodborne illness [13]. The food code presented by the U.S. Food and Drug Administration states that potentially hazardous food must be rapidly cooled from $57.5^{\circ} \mathrm{C}$ to $21.1^{\circ} \mathrm{C}$ in 2 hours or less, and from $21.1{ }^{\circ} \mathrm{C}$ to $5{ }^{\circ} \mathrm{C}$ in an additional 4 hours or less [14]. The importance of rapid cooling in preventing pathogens growing on food shows how heavily dependent restaurants are upon highly performing refrigeration systems.

Commercial food outlets in the UK are responsible for around 12 TWh of annual electrical consumption, about $3 \%$ of the UK total energy consumption and $1 \%$ of total Green House Gas (GHG) emissions [2]. Furthermore, the leakage of refrigerant from supermarkets which is accountable for $2 \mathrm{Mt} \mathrm{CO}_{2}$ emissions per year caused by the leakage of hydrofluorocarbons (HFC) [15]. Improving the performance of the refrigeration system has a huge potential in reducing electrical usage and costs. Furthermore, reducing electrical usage will consequently aid in the decrease of GHG emissions, particularly carbon dioxide, and lower the industries carbon footprint. Additionally, due to the food outlets in the UK operating on a small profit margin typically around $1-2 \%$, cost savings are vital. A large potential for energy savings has been identified $[2,16]$, as the refrigeration system can use up to $60 \%$ of the total store energy, they have been identified as an area of particular interest [17]. Therefore, further research and investigations are necessary to determine a reliable engineering approach of energy saving for commercial refrigeration systems. 
Refrigeration systems are a common feature in supermarkets for the preservation of chilled and frozen products. The layout of refrigeration system of the supermarket is shown in Figure 1. In supermarkets the refrigeration systems are split into low temperature (LT) systems for frozen products, and high temperature (HT) systems for non-frozen products [18]. All compressors operate at the same saturated suction temperature, often configured in packs where the compressors can be selected and cycled as needed to meet the refrigeration load [19]. The compressors compress the low-pressure refrigerant which is returning from the display case via the suction manifold to the condenser unit [18]. There are two levels of temperatures within food outlets which both have different purposes, $0-8{ }^{\circ} \mathrm{C}$ for the preservation of fresh products and beverages, and around $-18{ }^{\circ} \mathrm{C}$ for frozen products [16].

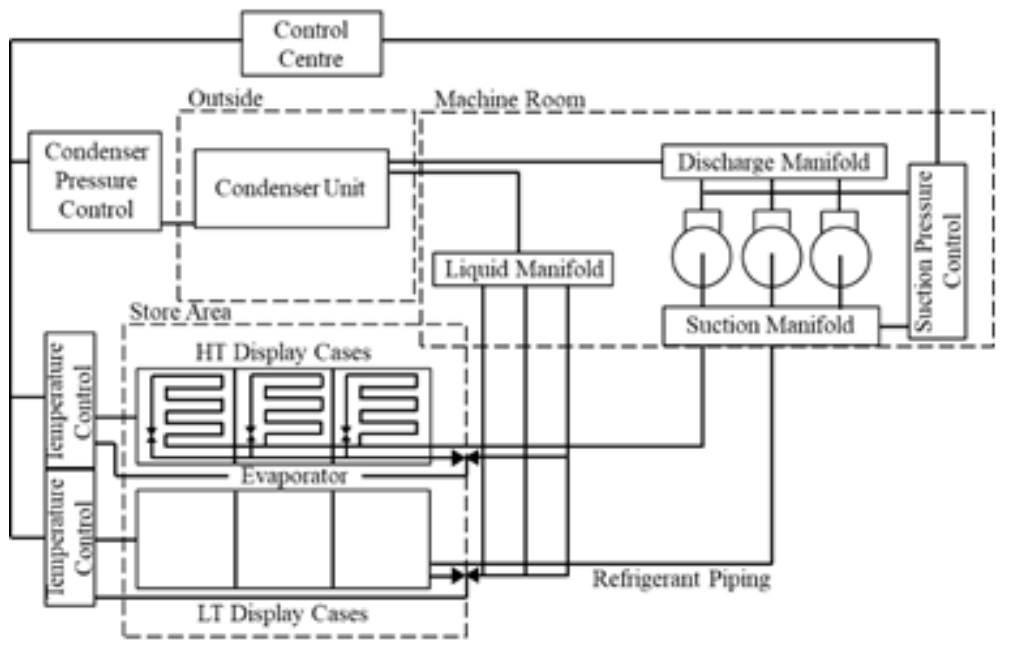

Figure 1: Typical refrigeration system layout (cited from [18]).

Tassou et al. [20] reported that food outlets in the UK are characterised by their average sales area and their annual average electrical energy consumption. The electrical energy consumption for refrigeration system is expected to be higher within smaller supermarkets and convenience stores as they have a higher focus on chilled and frozen foods with less additional services instore to consume electricity. In 81 the food industry, refrigeration systems account for between $30 \%$ and $60 \%$ of the electricity used with hypermarket refrigeration systems accounting for $29 \%$ of their annual consumption [21]. 
Due to the growing demand on refrigeration systems, there has been remarkable interest in developing more efficient and better performing systems [22]. Larsen [18] developed a nonlinear dynamic mathematical model of supermarket refrigeration system. The model is a combination of individual models for the display cases, suction manifold and compressor pack with the main emphasis on modelling the suction manifold and display cases. Peterson et al. [23] adapted the model of Larsen [18] with more focus on optimisation of supermarket refrigeration systems. A classic control setup introduced disturbances and the dynamic coupling of the cases caused the synchronization of compressors, which leads to lowering the system efficiency.

Shafiei et al. [22] developed a supermarket refrigeration system for smart grid applications with the focus primarily on estimating the compressor power consumption and cold reservoir temperatures.

A mathematical model to simulate the performance of a supermarket refrigeration system has been proposed by Y.Ge and S. Tassou [24]. The model allows for comparison between different systems in terms of their energy and total equivalent warming impact, where the total equivalent warming impact was defined as the sum of the direct and indirect emissions of greenhouse gases.

Sarabia et al. [25] proposed a nonlinear continuous-time model to investigate a nonlinear model predictive control (MPC) and to calculate the output predictions. The model was inspired by a publication from Larsen et al [26].

Glavan et al. [27] developed a dynamic model refrigeration system that can determine the impact of component efficiency and losses due to interaction with the system. A state-space model has been presented which represents a linear heat transfer dynamic of the display case with the real temperature dynamics used. The work done in [27] was inspired by the work of Vinther et al [28] where a model has been presented to aid in the investigation of a precooling algorithm.

Posnikov et al. [29] presented a large scale control model of a retail refrigeration system for a static firm frequency response. Two methods of control were tested, modulation and hysteresis, however hysteresis lead to undesired load oscillations following a shedding event. The study also shows that active power fluctuates in response to a frequency balancing event, allowing the system to be linked to a power grid model to simulate power loss. Saleh et al. [30] and Albayati et al. [31] investigated the impact of 
responding to demand side response events on the performance of the commercial refrigeration system,

111 using a large network of compressor packs.

112 The aim of this research is to develop and simulate a refrigeration system model for a commercial

113 application in order to examine and investigate the impact of various operational parameters on the

114 performance of the refrigeration system. A mathematical and validated refrigeration system model,

115 which is capable of simulating a 2000 sqft commercial refrigeration system, will be developed.

\section{2- Commercial Refrigeration System Description}

118 The model proposed in this research will mimic a typical $2000 \mathrm{sq} f \mathrm{ft}$ Express Supermarket located at the

119 Riseholme Refrigeration Research Centre at the University of Lincoln. Figure 2 shows the layout of the store which comprises of 13 high temperature (HT) display cases, of two different model (Atlas FHGD \& Monza FHGD), and 2 low temperature (LT) freezers, model (Hockenheim). The HT case installed at the site is shown in Figure 3. A hysteresis controller is used to control the temperature of each display case and functions using upper and lower temperature set points. When the temperature rises to the

124 upper setpoint, the expansion valve fully opens to allow additional refrigerant into the evaporator. Once 125 the temperature falls below the lower setpoint, the valve closes. The upper and lower setpoints for the 126 HT display cases are set at $3{ }^{\circ} \mathrm{C}$ and $0{ }^{\circ} \mathrm{C}$ respectively, while the LT freezer setpoints are $-21{ }^{\circ} \mathrm{C}$ and $23{ }^{\circ} \mathrm{C}$. The temperature setpoints of the LT display cases are set using readings from the $T_{\text {air-off }}$ probe.

128 While the HT display cases are set using a combination of the $T_{\text {air-on }}$ and $T_{\text {air-off }}$ probes with a 129 weighting applied of $40 \%$ from $T_{\text {air-on }}$ and $60 \%$ from $T_{\text {air-off }}$. The case controllers used are Danfoss 130 514B and Danfoss 550 while the HT expansion valves are AKV10 and the LT expansion valves are 131 TEX [30].

132 Both the HT and LT systems have separate suction lines which are maintained at 3.4 bar and 0.7 bar, 133 respectively, and discharge the refrigerant to a common liquid line which is at a constant pressure of 11 134 bar. The compressor pack is comprised of a total of 6 Copeland scroll compressors, (4 HT compressors 135 model of model of ZB45KCE, and 2 LT compressors are ZF09K4E and ZF15K4E, all compressors 
136 operate with fixed volume displacements, hence they operate at $100 \%$ capacity. The average power

137 drawn by each individual compressor is around $4.25 \mathrm{~kW}$. The compressor pack layout functions to create

138 one-stage compression for both HT and LT suction lines independently. Figure 4 shows the compressor

139 pack at the Riseholme Refrigeration Research Centre [29, 30].

140 The compressor pack runs in a FIFO (First-in First-out) sequence in order to maintain the desired suction

141 line pressure. This sequence operates so that more compressors turn on once the suction pressure reaches

142 an upper bound and all shut off once a lower bound is reached. Around the reference pressure is a neutral

143 margin in which none of the compressors are turned on nor off as illustrated in Figure 5 [29] and [32].

144 The refrigerant used in this system is R407F. This is a zeotropic blend of R125, R32 and R134A

145 designed to replace less fuel efficient and environmentally friendly refrigerants such as R407A or

146 R404A. The Global Warming Potential (GWP) of R407F is 1824 compared to the higher values of

147 R407A or R404A being 2107 and 3922 respectively, giving up to 40\% lower carbon emissions [33-35].

148 The high critical temperature value of $82.7^{\circ} \mathrm{C}$ ensures that the refrigerant will be fully liquified in the

149 condenser, ensuring that the refrigerant into the evaporator, $\dot{m}_{r e f, i n}$ is in a $100 \%$ liquid state. This allows

150 for the maximum heat transfer to occur, helping to lower power consumption and decrease energy usage

151 by up to $15 \%$ when compared to R404A [34]. A summary of the commercial refrigeration system

152 parameters used in the presented model is displayed in Table 1. 
001-013 (High Temperature Cases, HT1-HT13)

020-021 (Low Temperature Cases, LT1 and LT2)

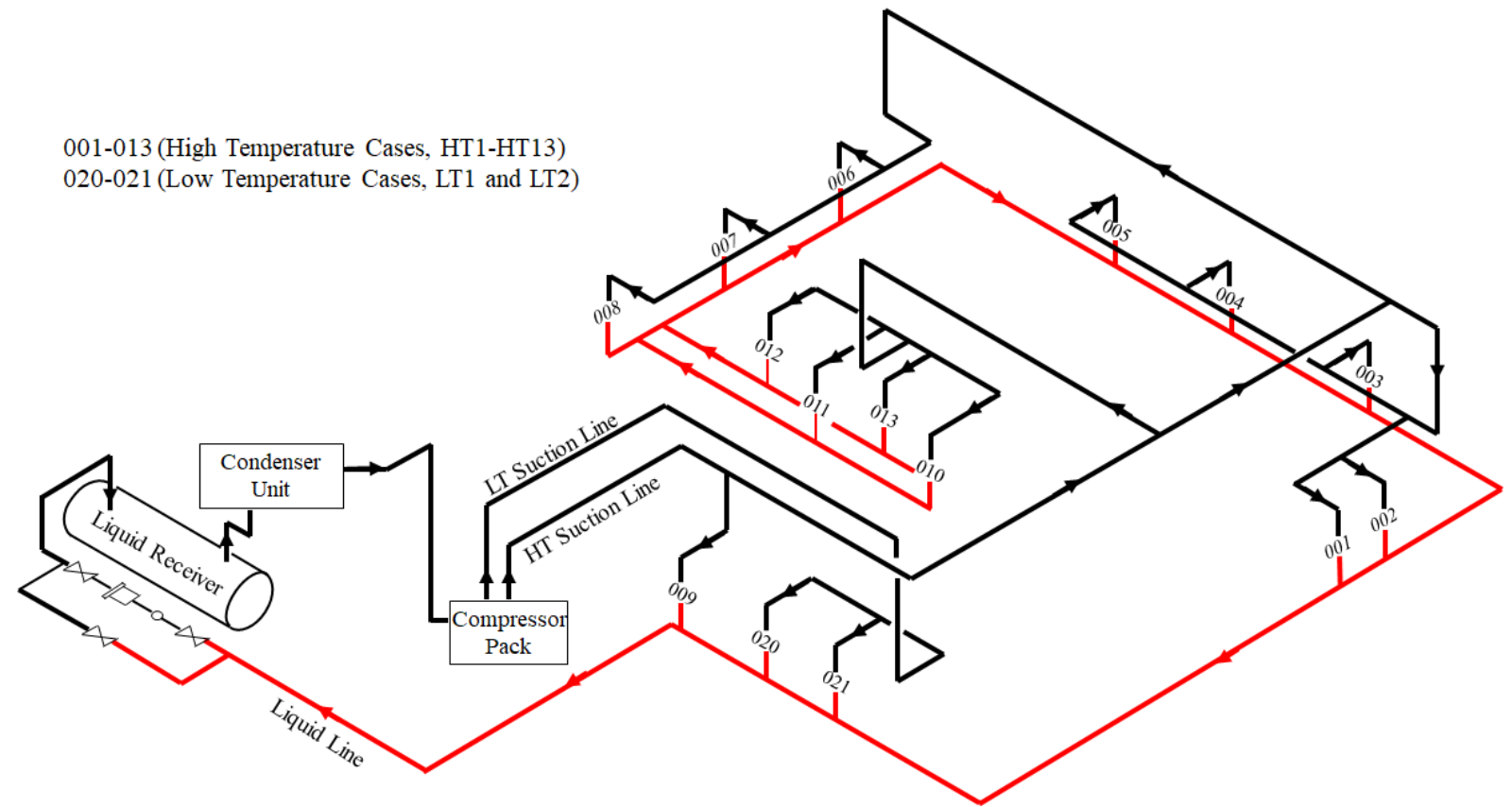

Figure 2: Schematic layout of Riseholme Refrigeration Research Centre at (cited form [30]).

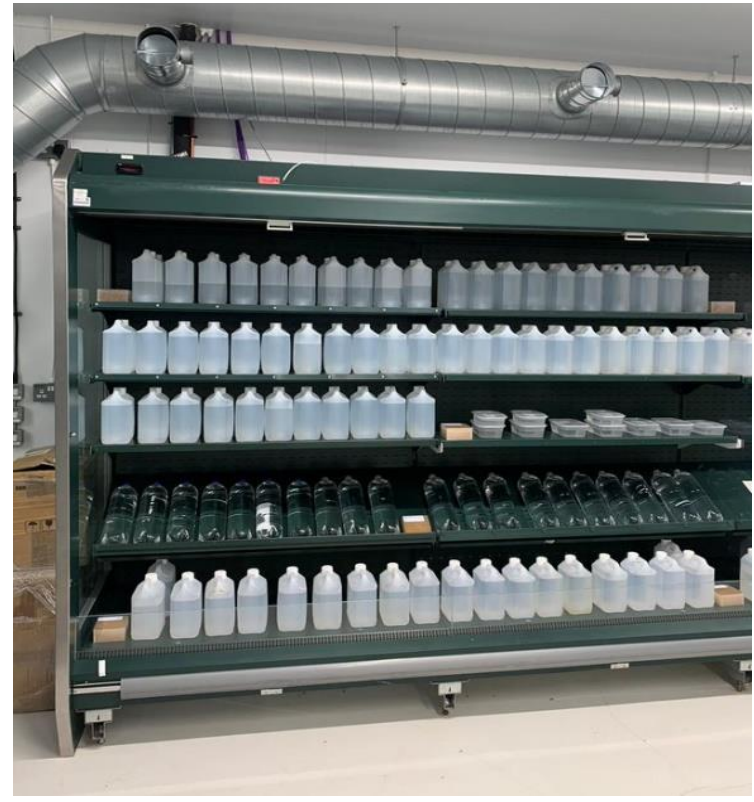

Figure 3: High temperature (HT) Monza display case used at Riseholme Refrigeration Research Centre.

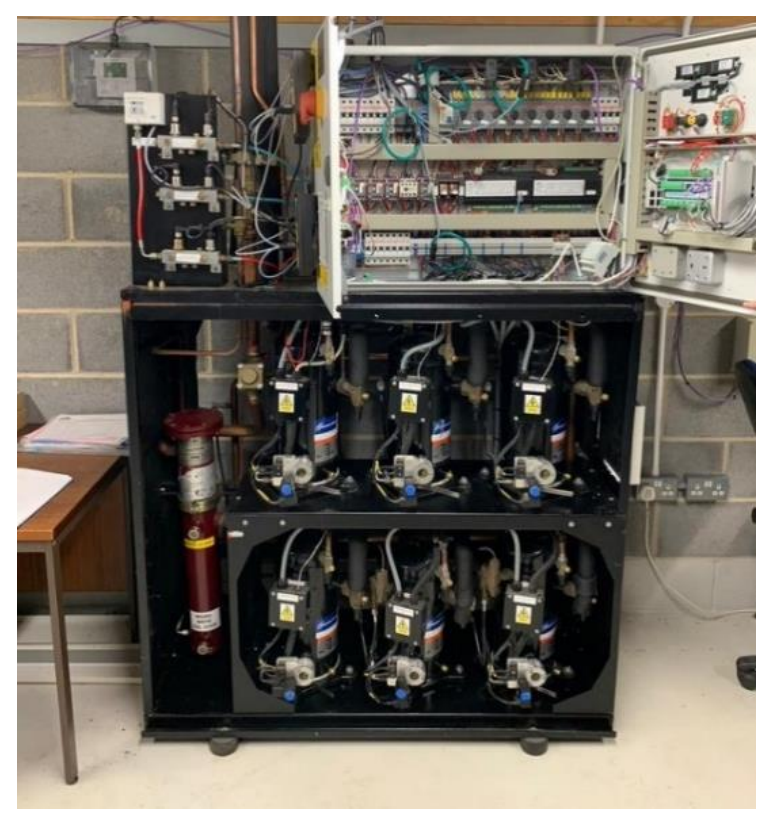

Figure 4: Compressor pack and controller used at the Riseholme Refrigeration Research Centre. 


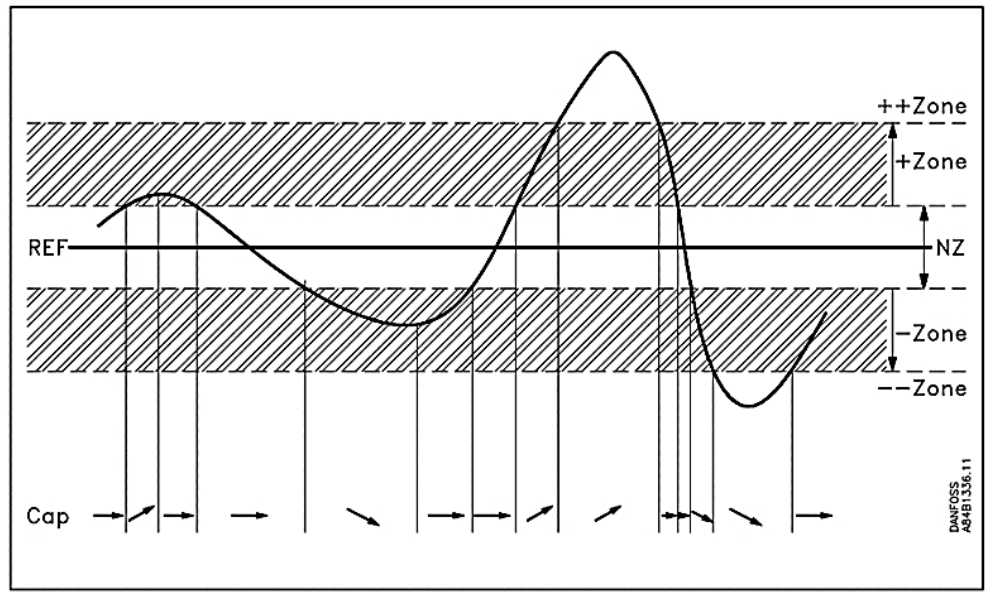

Figure 5: First-in first-out (FIFO) compressor operation cycle (cited form [32]).

Table 1: Summary of the system parameters used in the presented model [29, 30] and [36-38].

\begin{tabular}{|c|c|c|c|}
\hline Component & Parameters & Parameter Description & Value \\
\hline \multirow{8}{*}{$\begin{array}{l}\text { Display Cases } \\
\text { and Expansion }\end{array}$} & - & Number of HT cases & 13 \\
\hline & - & Number of LT cases & 2 \\
\hline & $V_{\text {Evap,max }}$ & Maximum volume of the Evaporator & $0.019 \mathrm{~m}^{3}$ \\
\hline & $C v$ & Collection of Valve Constants & $4.72 \mathrm{e}-6 \mathrm{~s} / \mathrm{m}^{2}$ \\
\hline & HT Temperature & HT Upper Setpoint & $3{ }^{\circ} \mathrm{C}$ \\
\hline & Setpoints & HT Lower Setpoint & $0^{\circ} \mathrm{C}$ \\
\hline & LT Temperature & LT Upper Setpoint & $-21{ }^{\circ} \mathrm{C}$ \\
\hline & Setpoints & LT Lower Setpoint & $-23^{\circ} \mathrm{C}$ \\
\hline \multirow{7}{*}{ Compressor } & \multirow{3}{*}{$\dot{V}_{d}$} & HT Compressor Displacement Volume & $0.0047 \mathrm{~m}^{3} / \mathrm{s}$ \\
\hline & & LT Compressor 1 Displacement Volume & $0.0022 \mathrm{~m}^{3} / \mathrm{s}$ \\
\hline & & LT Compressor 2 Displacement Volume & $0.0040 \mathrm{~m}^{3} / \mathrm{s}$ \\
\hline & - & Number of HT Compressors & 4 \\
\hline & - & Number of LT Compressors & 2 \\
\hline & - & FIFO Neutral Offset & $10.1 \mathrm{kPa}$ \\
\hline & - & FIFO Additional Offset & $15.2 \mathrm{kPa}$ \\
\hline Discharge Line & $P_{\text {rec }}$ & Pressure in the Receiver & $1114 \mathrm{kPa}$ \\
\hline
\end{tabular}




\section{3- Modelling a Commercial Refrigeration System}

162 For the purpose of modelling the system, models developed by Larsen [18] and Petersen et al [23] are

163 adopted, with additional contributions provided from Shafei et al [22], Sarabia et al [25] and Vinther

164 [40] which formatted and utilised equations on the evaporator, expansion valve and compressor pack 165 that better defined our system and modelling. Existing models by Postnikov et al in [29] and [39] based

166 on the Riseholme Refrigeration Research Centre are used to provide specific theory and understanding 167 of the facility itself.

168 Models developed by Larsen [18] who produced a model for the display cases, suction manifold and 169 compressor pack, and Petersen et al [23] who focussed on optimisation of refrigeration systems, are 170 adopted. Shafei et al [22], Sarabia et al [25] and Vinther [40] formatted and utilised equations on the 171 compressor pack, suction manifold and expansion valve respectively.

172 In this paper, a model composed of four main subsystems is developed: the expansion valve and the 173 evaporator of the display cases, the suction lines, the compressor pack, and the condenser, as shown in

174 Figure 6. These individual models are then combined to model a full commercial refrigeration system, 175 allowing for different system configurations to be tested effectively. Particular emphasis during 176 modelling will be given on the display cases and the compressor pack in order to accurately estimate 177 food temperature and its safety, as well as power consumption. The model presented in this paper differs 178 from Shafei et al [22] due to the condenser being assumed to return $100 \%$ saturated liquid. Additionally, 179 the developed model will be validated using a real data from a functioning refrigeration system at the

180 Riseholme Refrigeration Research Centre to ensure accuracy of simulation. Moreover, the developed 181 model will be capable of estimating the refrigerant properties, power consumption and system 182 temperatures, as well as investigations into store/system parameters and their effect on power 183 consumption. 
185
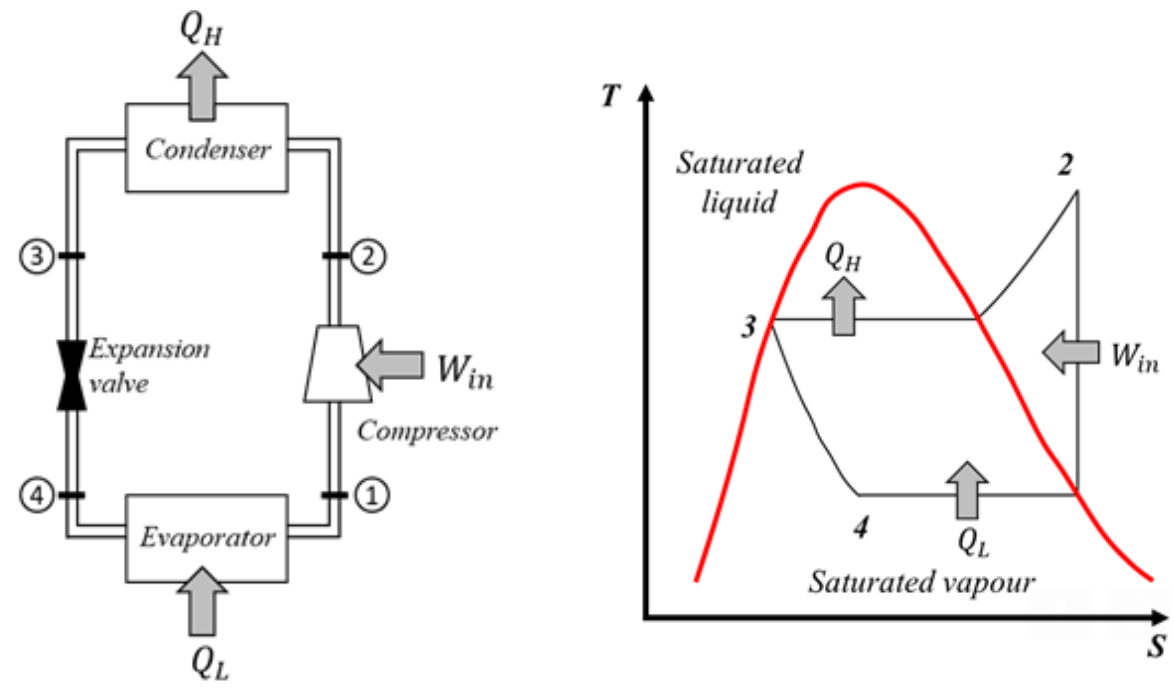

Figure 6: Main subsystems and refrigeration cycle for the refrigeration system.

In order to simplify the model, it is assumed that the condensers have a full condensation with a $100 \%$ liquid return, and the condenser dynamics and the pressure within the return line are stable, therefore any changes that occur are negligible in the overall system. A static relation can therefore be used to calculate properties in the condenser with the liquid line, receiver and condenser assumed to be constant at 11 bar, it has also been assumed that subcooling is constant [29] and [39]. The refrigerant properties used are calculated using the REFPROP database. The developed system is modelled using a refrigerant R407F [41].

\subsection{Display Cases: Expansion Valve \& Evaporator}

In a commercial refrigeration system, the display cases provide a low-temperature environment for the products to be safely stored. The display case consists of evaporator, expansion valve, and storage compartment. Inside the display case, the heat from the products is transferred to the evaporator via a circulating air-curtain. From here the energy is transferred to the low-pressure liquid refrigerant, causing it to evaporate and superheat it. The superheated vapour is then drawn out of the evaporator and through the suction line by the compressors $[18,23]$. Incoming refrigerant to the evaporator is controlled by the 
expansion valve which regulates the mass flow rate of the refrigerant by adjusting the opening degree

204 of the valve. The valve also drops the pressure of the refrigerant so that it is easily vaporised, allowing 205 for heat to be removed from the display case [18]. The dynamics of the display cases are derived from 206 creating an energy balance for the products, evaporator, and air inside the display case along with a mass balance for the refrigerant in the evaporator. For this model all frictional and minor losses assumed to be negligible. Figure 7 shows a typical layout of the high temperature (HT) commercial refrigeration display case which is used to derive the main equations in this research [18, 25, 39].

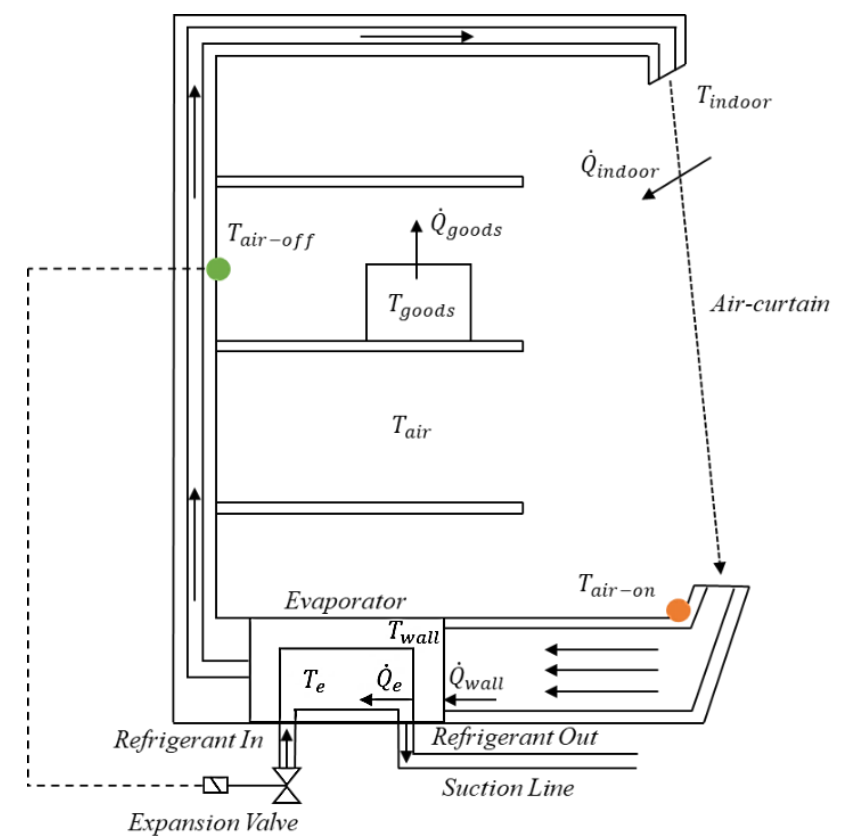

Figure 7: High temperature (HT) display case schematic.

214 Assuming a lumped temperature model, the following state equations are then given by [18, 23]:

$$
\begin{aligned}
& \frac{d T_{\text {products }}}{d t}=\frac{-\dot{Q}_{\text {products }}}{m_{\text {products }} C_{\text {p,products }}} \\
& \frac{d T_{\text {air }}}{d t}=\frac{\dot{Q}_{\text {products }}+\dot{Q}_{\text {indoor }}-\dot{Q}_{e}}{m_{\text {air }} C_{\text {p,air }}}
\end{aligned}
$$

215 where $m, t$ and $C_{p}$ are the mass, time and the heat capacity respectively, with each subscript denoting 216 the media which the parameter refers to, $\dot{Q}_{\text {products }}$ is the heat transfer from the products to the air inside 
the display case, $\dot{Q}_{\text {indoor }}$ is the heat load from the indoor supermarket store temperature to the air inside

218 the display case, and $\dot{Q}_{e}$ is the heat transfer from the air inside the display case to the refrigerant in the 219 evaporator and is also termed the cooling capacity. The two states are therefore, $T_{\text {products }}$ and $T_{\text {air }}$ 220 which are the temperature of the products and air inside the display case, respectively. The energy flows 221 are then defined by [23]:

$$
\begin{gathered}
\dot{Q}_{\text {products }}=U A_{\text {products }}\left(T_{\text {products }}-T_{\text {air }}\right) \\
\dot{Q}_{\text {indoor }}=U A_{\text {indoor }}\left(T_{\text {indoor }}-T_{\text {air }}\right) \\
\dot{Q}_{e}=U A_{e}\left(T_{\text {air }}-T_{e}\right)
\end{gathered}
$$

where $U A$ is the overall heat transfer coefficient with the subscript denoting the media which the heat is transferred across, $T_{\text {indoor }}$ is the indoor store temperature of the supermarket, and $T_{e}$ is the evaporation temperature of the refrigerant which is a function of pressure and is dependent on the refrigerant used in the system $[18,23,25]$. This is therefore calculated from the suction line dynamics using the refrigerant properties database REFPROP [41]. Combining Equations (1) and (3) and solving for the product temperature leads to:

$$
T_{\text {products }}=T_{\text {air }}\left(T_{\text {products,initial }}-T_{\text {air })} e^{\left(\frac{U A_{\text {products }} \cdot t}{\left.m_{\text {products } C_{p, p r o d u c t s}}\right)}\right)}\right.
$$

where $T_{\text {products,initial }}$ is the initial temperature of the products at the start of the system simulation. Combining Equations (2) and (6) and assuming the specific heat capacity of the air is close to zero, Equation (2) can be solved to find the temperature of the air inside the display case, $T_{\text {air }}$ [23]:

$$
T_{\text {air }}=\frac{U A_{\text {products }} T_{\text {products }}+U A_{\text {indoor }} T_{\text {indoor }}+U A_{e} T_{e}}{U A_{\text {products }}+U A_{\text {indoor }}+U A_{e}}
$$

232 In order to monitor the range of temperatures of the air inside the display case, two temperature probes 233 are used. These are positioned at the front and rear of the display case with the probe at the front being 234 'on' the air curtain and the rear probe being 'off' the air curtain, giving them the names $T_{\text {air-on }}$ and 
$235 T_{\text {air-off }}$ respectively. The readings from the $T_{\text {air-off }}$ probe is a calculated ratio between $T_{\text {air }}$ and $T_{e}$, 236 similarly $T_{\text {air-on }}$ is calculated from a ratio between $T_{\text {air }}$ and $T_{\text {indoor }}$ [29]:

$$
\begin{gathered}
T_{\text {air-off }}=\propto T_{\text {air }}+(1-\propto) T_{e} \\
T_{\text {air-on }}=\beta T_{\text {air }}+(1-\beta) T_{\text {indoor }}
\end{gathered}
$$

237 where $\alpha$ and $\beta$ are empirical coefficients that are dependent on the type of display case, location in the 238 supermarket and outdoor temperature [29]. The heat transfer coefficient between the evaporator and the 239 refrigerant, $U A_{e}$ is assumed to be a linear function of the mass of liquefied refrigerant in the evaporator, $240 m_{\text {ref }}[18,22]:$

$$
U A_{e\left(m_{r e f}\right)}=k_{m} U A_{e}
$$

241 where $k_{m}$ is defined as the ratio of the mass of refrigerant in the evaporator, to the maximum capacity 242 of the evaporator, $m_{\text {ref, } \max }[18,22]$ :

$$
k_{m}=\frac{m_{r e f}}{m_{\text {ref, } \max }}
$$

243 Due to the variations of pressure and temperature of the liquified refrigerant inside the evaporator, the 244 density therefore varies as a result. Therefore, $m_{\text {ref, } \max }$ is constrained by the maximum volume of the 245 evaporator $V_{\text {Evap,max }}$ and the density of the liquified refrigerant $\rho_{\text {liq,suc }}$ which is calculated using the 246 REFPROP database [41]:

$$
m_{\text {ref,max }}=V_{\text {Evap, } \max } \times \rho_{\text {liq, suc }}
$$

247 The rate of change of refrigerant in the evaporator $\frac{d m_{r e f}}{d t}$ is defined by the mass balance in and out of 248 the evaporator [22, 23]:

$$
\frac{d m_{r e f}}{d t}=\dot{m}_{r e f, \text { in }}-\dot{m}_{r e f, o u t}
$$

249 where $\dot{m}_{r e f, \text { in }}$ and $\dot{m}_{r e f, \text { out }}$ are the mass flow rate of the refrigerant in and out of the evaporator, 250 respectively. The mass flow rate entering the evaporator is controlled by the expansion valve via 
regulating the opening degree of the valve. This is governed by Bernoulli's equation, assuming laminar

252 flow and no change in elevation [40]:

$$
\dot{m}_{\text {ref,in }}=O D \cdot C v \cdot \sqrt{\rho_{\text {liq, rec }}} \cdot \sqrt{P_{\text {rec }}-P_{\text {suc }}}
$$

253

254

where $m_{s u c}$ is the total mass of refrigerant in the suction line, the mass flow rate enter the suction line

where $O D$ is the opening degree of the valve with 0 being fully closed and 1 being fully open, $C v$ is a collection of constants such as the cross-sectional area of the valve inlet and outlet, and can also be termed the orifice coefficient or valve characterising constant [23,40], and $P_{r e c}$ and $P_{s u c}$ are the pressure in the receiver and the suction line, respectively. The mass flow rate of refrigerant leaving the evaporator is assumed to be $100 \%$ dry vapour with a constant superheat temperature and is given by [40]:

$$
\dot{m}_{r e f, \text { out }}=\frac{\dot{Q}_{e}}{h_{l g, \text { out }}-h_{l g, \text { in }}}
$$

where $h_{l g, o u t}$ and $h_{l g, i n}$ are the enthalpies of the refrigerant at the outlet and inlet of the evaporator, respectively [40]. These enthalpies are calculated from the suction line pressure using the REFPROP database [39, 41]. By combining Equations (10) to (15), the accumulation of refrigerant in the evaporator can be calculated and therefore the overall heat transfer coefficient between the refrigerant and evaporator can be determined.

\subsection{Suction Line}

The suction line is modelled by a dynamic equation with one state $P_{s u c}$ of the suction pressure. Establishing the mass balance across the suction line [23]:

$$
\frac{d m_{s u c}}{d t}=\dot{m}_{s u c, i n}-\dot{V}_{c o m p} \rho_{s u c}
$$

is the sum of all mass flow rates leaving each of the display case evaporators [23]:

$$
\dot{m}_{\text {suc }, \text { in }}=\sum_{i}^{N_{D C}}\left(\dot{m}_{\text {ref }, \text { out }, i}\right)
$$


where $N_{D C}$ is the number of display cases, $\dot{m}_{s u c, \text { in }}$ is the mass flow rate enter the suction line, and $270 \dot{m}_{\text {ref,out }, i}$ is the mass flow rate of the refrigerant leaving the evaporator. Rewriting the mass derivative 271 in terms of volume, density and pressure yields [23]:

$$
\frac{d m_{\text {suc }}}{d t}=V_{\text {suc }} \frac{d \rho_{\text {suc }}}{d t}=V_{\text {suc }} \frac{d \rho_{\text {suc }}}{d P_{\text {suc }}} \frac{d P_{\text {suc }}}{d t}
$$

272 where $V_{\text {suc }}$ and $\rho_{\text {suc }}$ is the volume and density of the refrigerant in the suction line, respectively. By 273 combining Equations (16) and (18) and rearranging for $\frac{d P_{s u c}}{d t}$, the final dynamic equation for the suction 274 line is [23]:

$$
\frac{d P_{s u c}}{d t}=\frac{\dot{m}_{s u c, i n}-\dot{V}_{c o m p} \rho_{s u c}}{V_{s u c} \frac{d \rho_{s u c}}{d P_{s u c}}}
$$

275 where $\dot{V}_{\text {comp }}$ is the volumetric flow rate leaving the suction line and is determined from the compressor 276 duty cycle [23].

\subsection{Compressor Pack}

279 The compressor pack receives the refrigerant from the display cases via the suction line. It compresses 280 the low-pressure gaseous refrigerant up to a higher pressure which then flows into the condenser. This 281 increase in pressure also leads to an increase in temperature. The compressors in this system operate as 282 discrete fixed volumes, thus each compressor is either running at maximum capacity or is totally off, 283 and the operation of the compressors are functioned to the suction line pressure. Moreover, turning on 284 more compressors will decrease the volume of refrigerant in the suction line which thereby lowers the 285 suction pressure. The flow rate of the compressors can therefore be modelled as [23]:

$$
\dot{V}_{\text {comp }}=N_{\text {comp }} \dot{V}_{d} \eta_{v o l}
$$

286 where $N_{\text {comp }}$ is number of running compressors, $\dot{V}_{d}$ is the maximum displacement volume flow rate of 287 each compressor, and $\eta_{v o l}$ is the clearance volumetric efficiency [22]. The average power drawn by one 
compressor running at maximum capacity is $4.25 \mathrm{~kW}$, therefore the total compressor power consumption

can be found in Equation (21) [29]:

$$
\dot{W}_{\text {comp }}=4.25 N_{\text {comp }}
$$

290

291

292

293

294

295

296

297

298

299

300

301

302

303

$$
C P T_{k}=\frac{1}{30}\left(\sum_{i=1}^{29} C P T_{k-i}+T_{\text {shelf }}^{k}\right)
$$

304

where the subscript $k$ denotes the minute at which the measurements and calculations are done. $T_{\text {shelf }}$ can be calculated from readings taken by the air-on and air-off probes located in each of the cases as 307 follows [29, 30]:

$$
T_{\text {shelf }}=0.6 T_{\text {air-off }}+0.4 T_{\text {air-on }}
$$

where $\dot{W}_{\text {comp }}$ is the power consumption $(\mathrm{kW})$ of the entire compressor pack.

In order to tune and validate the developed refrigeration system model, Matlab and Simulink is used to simulate the operation of the developed model. The results of the model simulation will be analysed and compared with real operational data collected from the refrigeration system at Riseholme Refrigeration Research Centre. The real operational data has been collected on $18^{\text {th }}$ March 2017 during a 3-hour period between 08:30 and 11:30, with a data granularity of 1 sample per minute, and an average store temperature of $16{ }^{\circ} \mathrm{C}$. The parameters of the system are tuned in order to validate and create a resemblance between the real data and the simulation results are as shown in Table 2 .

Due to the practical difficulties involved in directly measuring the product temperature, a filtered, 30minute moving average based off the shelf temperature, $T_{\text {shelf }}$, is used to provide a calculated product temperature (CPT) for each case. This can be described as [29, 30]: 
Table 2: Tuned parameters used for the validation of the developed model.

\begin{tabular}{|c|c|c|c|}
\hline Components & Parameters & Parameter Description & Values \\
\hline \multirow{7}{*}{ Display Cases } & $\propto$ & Empirical coefficient of $T_{\text {air-off }}$ & 0.952 \\
\hline & $\beta$ & Empirical coefficient of $T_{\text {air-on }}$ & 0.970 \\
\hline & $U A_{\text {products }}$ & $\begin{array}{l}\text { Heat transfer coefficient between } \\
\text { Products and air inside DC }\end{array}$ & $0.001 \mathrm{~kW} / \mathrm{K}$ \\
\hline & $U A_{\text {indoor }}$ & $\begin{array}{c}\text { Heat transfer coefficient between } \\
\text { indoor and air inside HT DC }\end{array}$ & $0.032 \mathrm{~kW} / \mathrm{K}$ \\
\hline & $U A_{e, f u l l}$ & $\begin{array}{c}\text { Maximum heat transfer coefficient } \\
\text { between DC air and liquified } \\
\text { refrigerant in evaporator }\end{array}$ & $0.450 \mathrm{~kW} / \mathrm{K}$ \\
\hline & $m_{\text {products }}$ & Mass of Products & $1200 \mathrm{~kg}$ \\
\hline & $C_{p, \text { products }}$ & Specific latent heat of Products & $4.18 \mathrm{~kJ} / \mathrm{kg}$ \\
\hline Suction Line & $V_{\text {suc }}$ & HT Suction line volume & $0.5 \mathrm{~m}^{3}$ \\
\hline
\end{tabular}

311 The air-on, air-off, and product temperatures for the simulation results of the developed model and for 312 the collected real data are shown in Figures 8 and 9, respectively. The operation of the expansion valve

313 for the developed model and for the real data are shown in Figures 10 and 11, respectively.

314 From Figures 8 and 9, the general trends for both the simulation and real data closely resemble each 315 other throughout the 3 hour period. The product temperature determined by the air-on and air-off 316 temperatures is $2.1{ }^{\circ} \mathrm{C}$ for both the simulation and real data. Additionally, both the air-on and air-off 317 temperatures have similar maximum values. For air-on, $3.87{ }^{\circ} \mathrm{C}$ for the simulated results and $4{ }^{\circ} \mathrm{C}$ for 318 the real data. While for air-off, $3.02{ }^{\circ} \mathrm{C}$ for the simulated results and $3{ }^{\circ} \mathrm{C}$ for the real data.

319 The simulation results consistently have lower minimum temperature values for both air-on and air-off 320 when compared to the real data. The minimum air-on temperatures were $0.25^{\circ} \mathrm{C}$ for the simulated results 321 and $2.3{ }^{\circ} \mathrm{C}$ for the real data, while the minimum air-off temperatures were $-0.78{ }^{\circ} \mathrm{C}$ for the simulated 322 results and $-0.4{ }^{\circ} \mathrm{C}$ for the real data. This difference is caused by modelling all the 13 display cases as 
the same, and all acting at the same time, which causes an exaggerated demand on the system and leads

324 to lower temperatures in the display cases. Furthermore, the real data for the Riseholme Refrigeration

325 Centre features two different HT display types with a few different sizes, all acting on their individual

326 loads. However, the model presented in this paper assumes all 13 display cases are identical in types and loads.

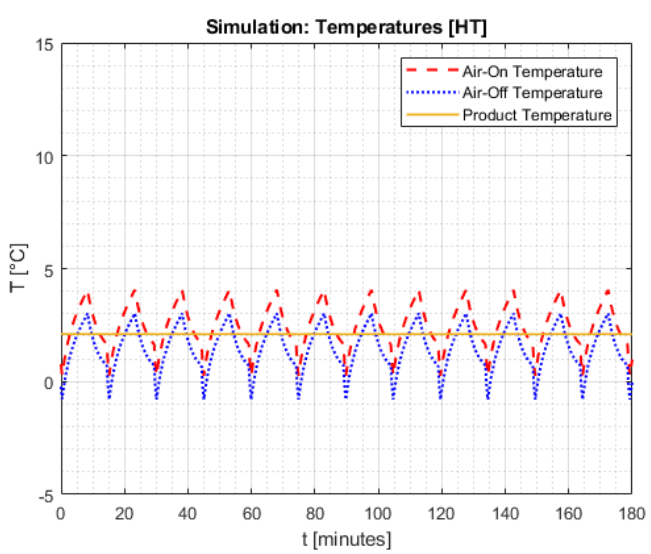

Figure 8: Simulation of the HT display temperatures for the developed refrigeration system model.

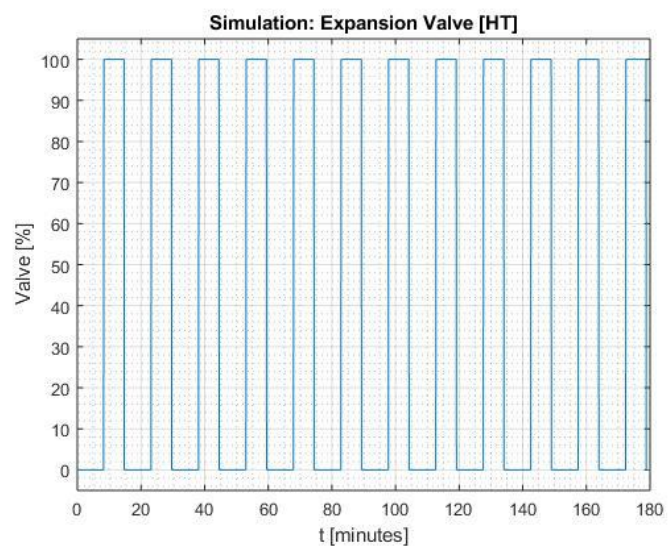

Figure 10: Simulation of the expansion valve Figure 11: Real operational data of the expansion operation for the developed refrigeration system valve for the refrigeration system. model.

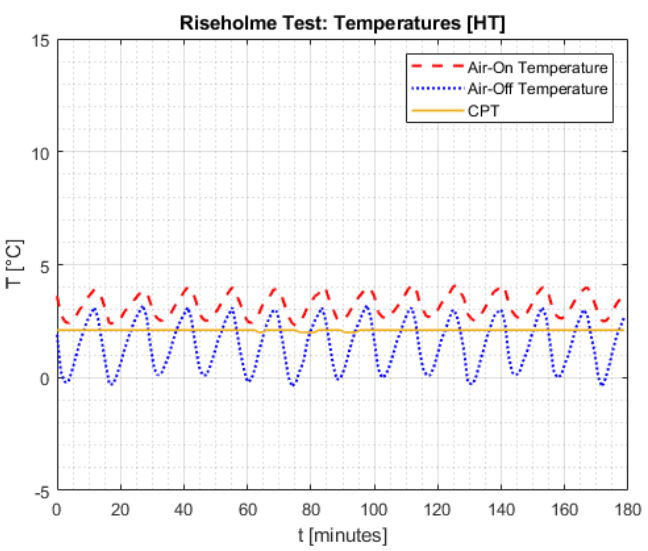

Figure 9: Real operational data for the HT temperatures of the refrigeration system.

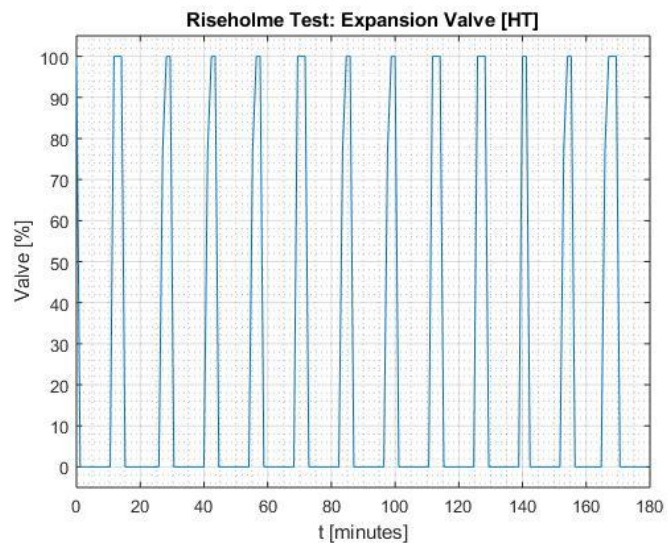

330 The sharp drop noted in Figure 8 near the bottom of the curve, occurred first at 14 minutes 25 seconds 331 and repeated every 15 minutes, is caused by the turning on of an additional compressor which causes 
332 the suction pressure to decrease suddenly. As the system models the evaporator temperature directly as

333 a function of the evaporator's pressure, an additional compressor turning on will cause immediate drop

334 in the temperature. Moreover, as the air-on and air-off temperatures cooled via evaporation of the 335 refrigerant into the suction line, the suction pressure increases. Once the display case reaches the lower set-point, the suction pressure reaches the set-point for a second compressor to turn on, causing a suction pressure to suddenly decrease, this translates to a sudden drop in temperature of the air-on and air-off

338 temperatures. The fluctuations in the air-off temperature in the HT system dictates the behaviour of the 339 expansion valve of each individual display case in order to maintain the temperature set points.

340 From Figures 10 and 11, both the simulation results and the real data contain 12 full on-off cycles of the 341 expansion valve for 3 hours period. The simulation expansion valve remains open for 6 minutes and 30 342 seconds, while for the real data the valve remains open for 4 minutes and 42 seconds. The greater 343 demand on the system explains the difference in the opening time for the expansion valve. Moreover, 344 in Figure 11, there is a difference in the width of the peaks for some of on-off cycles of expansion valve. 345 This is due to the sampling rate of real data which was 1 sample/minute, therefore a data point might be 346 taken while the valve is not fully open. This has consequently caused the recorded real data to show a 347 smaller time period where the expansion valve is open, however in reality this is not the case and it 348 would closer resemble the simulation data. Whilst the expansion valve is operating through an on-off 349 cycle, fluctuations in the suction pressure occur due to more evaporating refrigerant entering the suction 350 line or saturated vapour being pulled through the compressor.

351 The suction pressure of the refrigeration system for the simulation results of the developed model and 352 for the real data of the Riseholme Refrigeration Centre are shown in Figures 12 and 13, respectively. 


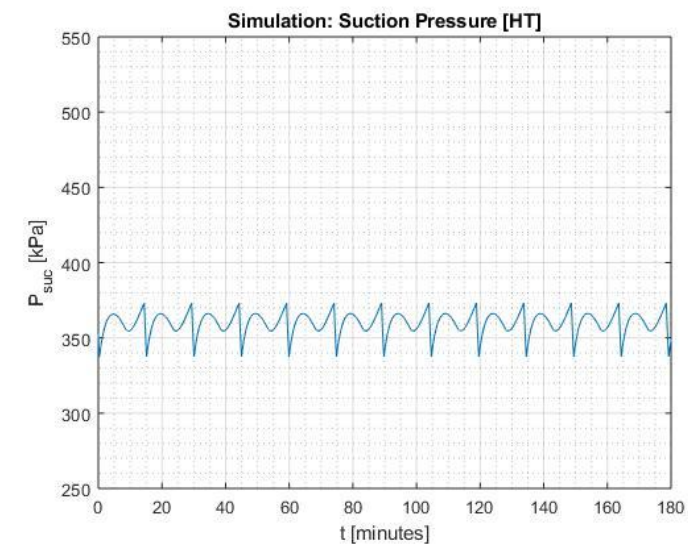

Figure 12: Simulation of the suction pressure for the high temperature system of the developed system at Riseholme Refrigeration Research Centre. refrigeration system model.

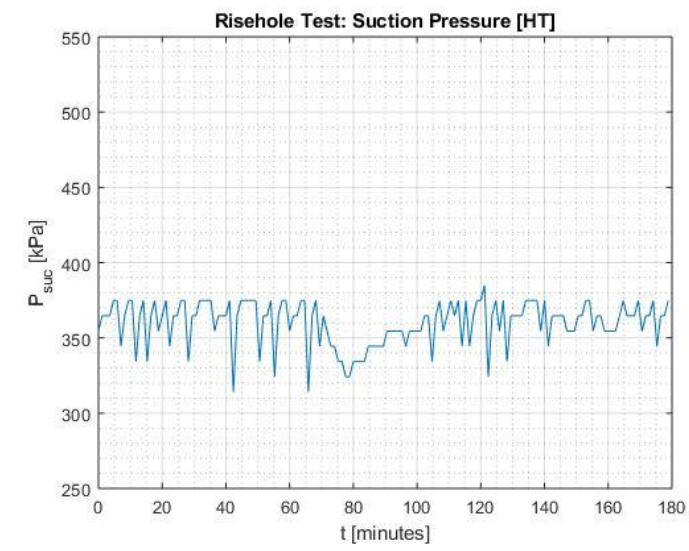

Figure 13: Suction pressure for the high temperature

355 From Figures 12 and 13, the suction pressure for both of the simulated model and the real data follow a 356 similar trend. However, there are some differences with the suction pressure over the 3 hours period, 357 due to the differences in the size and types of loads at Riseholme refrigeration system. Both the 358 simulation data and test data had similar maximum values reaching peaks of $374.8 \mathrm{kPa}$ and $373.3 \mathrm{kPa}$, 359 respectively. While, the minimum values for the simulation and real data were $334.3 \mathrm{kPa}$ and $338.9 \mathrm{kPa}$, respectively. Considering that the setting of the suction line pressure at Riseholme Refrigeration Research Centre was sat on $340 \mathrm{kPa}$ (3.4 Bar), the large random fluctuations due to the disturbances caused by the loads and the environment can be neglected.

363 The power consumption of the HT system for the simulation result of the developed model and for the 364 real data at Riseholme Refrigeration Research Centre are shown in Figures 14 and 15, respectively. It is 365 noticed that there was always at least one compressor running at full capacity, with an additional 366 compressor coming on occasionally when needed. An additional compressor turns on when the suction 367 pressure reaches the pre-defined set-point, which then reduced the suction pressure back to the desired value. Figure 14 shows the power drawn from the compressors during the simulation, there are 12 instances where an additional compressor kicks in to reduce the suction pressure in comparison to 19 instances for the data at Riseholme Refrigeration Research Centre as shown in Figure 15. This is due to 
the simulation assuming all display cases are of the same variety and acting with the same conditions

372 throughout, therefore all acting in the same way and uniformly throughout the testing period and 373 exaggerating the behaviours of the system. At the Riseholme Refrigeration Research Centre, there are 374 likely to be bigger changes in the suction line pressure due to the varying behaviour of each display case, resulting in more frequent variations in the suction pressure and therefore more instances for an additional compressor to kick in. Hence, a slight difference in the total energy drawn by the compressors

377 during the 3 hours period, with the simulation consuming a total of $17.25 \mathrm{kWh}$ and the Riseholme

378 Refrigeration Research Centre consuming a $14.18 \mathrm{kWh}$. The total energy consumption is shown in

379 Figures 16 and 17 for the simulation and the Riseholme Refrigeration Research Centre, respectively.

380 The Riseholme data would be expected to have more power drawn due to the higher occurrence of a 381 second compressor turning on. However, due to the Riseholme system logging data every minute compared to the simulation which logs data every second, samples are omitted when the second compressor is running, this ultimately reduces the total power drawn. Reducing the sample rate for the

384 simulations would reduce the error, however for the following simulations a larger sample rate was selected as it increases the accuracy of the data and gives a higher resolution of the system behaviour.

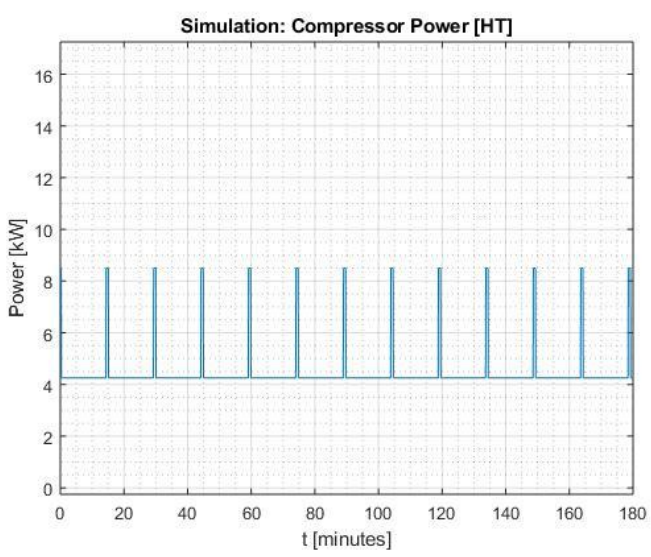

Figure 14: Simulation of the of power consumption for the HT compressors of the developed refrigeration system model.

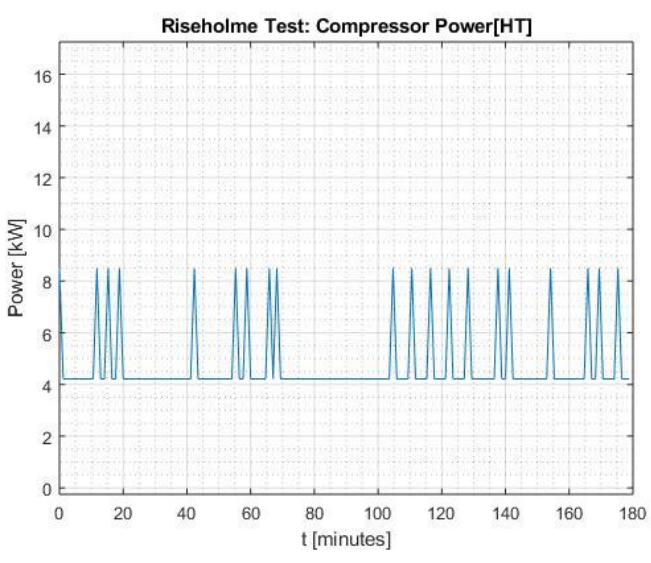

Figure 15: Power consumption for the HT compressors at Riseholme Refrigeration Research Centre. 


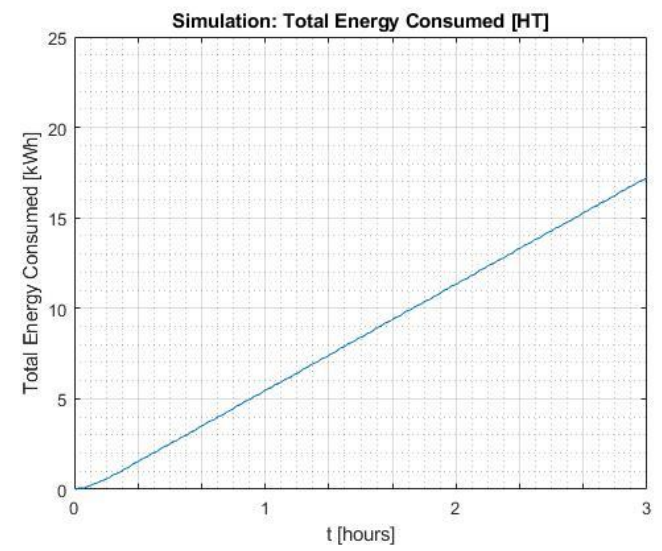

Figure 16: Total energy consumption for the HT compressors of the developed refrigeration system model.

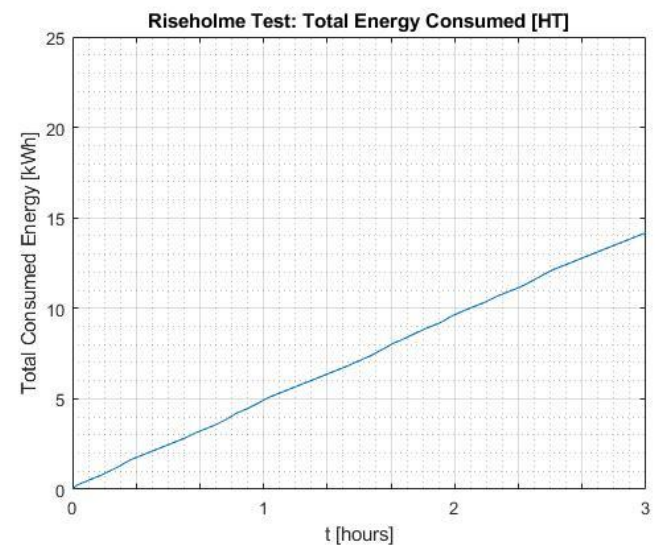

Figure 17: Total energy consumption for the HT compressors at Riseholme Refrigeration Research Centre.

\section{5- Conclusion}

388 In this paper, a validated model that simulates a commercial refrigeration system installed over 2000

389 sqft to mimic a real express store installed at Riseholme Refrigeration Research Centre at the University 390 of Lincoln, UK, is developed and presented. MATLAB/Simulink is used to simulate the operation of 391 the developed model which is tuned and validated with the real operational data collected from the 392 Refrigeration Centre. The modelled refrigeration system accurately simulated the operations of the display cases, suction line and compressor pack, with the condenser assumed to return $100 \%$ liquid.

394 Further emphasis has been given on the HT system, due to the HT display cases making up the majority 395 of the display cases in the commercial refrigeration system. Hence, the high temperature system has a 396 greater impact on the performance of the system and will be more sensitive to disturbances such as 397 external heat loads.

398 It is noticed that the simulation results of the developed model for the display cases temperatures, expansion valve opening degree, suction line pressures, and compressors power consumption, all having highly resemblance to the real operational collected data obtained from Riseholme Refrigeration

401 Research Centre, this supports the validation of the developed model. Further investigation needs to be 
402

carried to investigate the impact of the store temperate variations on the operation and the performance of the refrigeration system. Also, the implementation of Variable Frequency Drive (VFD) compressor that allows for a greater control and therefore a further saving of power consumption.

\section{Acknowledgement}

The authors would like to thank School of Engineering and Refrigeration Research Centre at the University of Lincoln for their cooperation and technical support.

\section{References}

[1] Gullpart, J., 2018, "Cold Chain Technology Brief: Refrigeration in Food Production and Processing," OzonAction.

[2] Tassou, S. A., Kolokotroni, M., Gowreesunker, B., Stojceska, V., Azapagic, A., Fryer. P., and Bakalis, S., 2014,"Energy demand and reduction opportunities in the UK food chain," Proceedings of the Institution of Civil Engineers-Energy, pp. 162-170.

[3] Olajire, A. A., 2012, "The brewing industry and environmental challenges," Journal of Cleaner Production.

[4] Schönberger, C., and Kostelecky, T., 2011, "125th anniversary review: the role of hops in brewing," Journal of the Institute of Brewing, pp. 259-267.

[5] Briley. G. C., 2003, "Refrigeration in large Breweries," ASHRAE journal, vol. 45, no. 2, p. 49.

[6] Shafaat. K., Hussain. A., and Hussain. S., 2013, "An overview: storage of pharmaceutical products," World J Pharm Sci, pp. 2499-2515.

[7] Kommanaboyina. B., and Rhodes. C. T., 1999, "Trends in stability testing, with emphasis on stability during distribution and storage," Drug development and industrial pharmacy, pp. 857868.

[8] Tassou. S., De-Lille. G., and Lewis. J., 2012, "Food transport refrigeration," Centre for Energy and Built Environment Research, School of Engineering and Design, Brunel University, UK, pp. $1-25$. 
[9] Tassou. S., De-Lille. G., and Ge. Y., 2009, "Food transport refrigeration-Approaches to reduce energy consumption and environmental impacts of road transport," Applied Thermal

[10] Smith. A., Watkiss. P., Tweddle. G., McKinnon. A., Browne. M., Hunt. A., Treleven C., Nash. C., and Cross. S., 2005, "The validity of food miles as an indicator of sustainable developmentfinal report," REPORT ED50254.

[11] Hafner. I. A., Gabrielii. C., and Widell. K., 2019, "Refrigeration units in marine vessels: Alternatives to HCFCs and high GWP HFCs." Nordic Council of Ministers.

[12] Sudheer. K., and Indira. V., 2007 "Post harvest technology of horticultural crops." New India

[13] Brown. L. G., Ripley. D., Blade. H., Reimann. D., Everstine. K., Nicholas. D., Egan. J., Koktavy. N., Quilliam. D. N., and E.-N. W. G. 1, 2012, "Restaurant food cooling practices," Journal of food protection, pp. 2172-2178.

[14] Fda. A, 1993, "Food Code. US Public Health Service," Food and Drug Adminis tration, Washington, DC.

[15] Suamir. I. N., 2012, "Integration of trigeneration and CO2 based refrigeration systems for energy conservation," Brunel University School of Engineering and Design PhD Theses.

[16] Protocol. M., and Layer. O., "Refrigeration, Air Conditioning and Heat Pumps Technical Options Committee."

448 [17] Briley. G. C., 2004, "A history of refrigeration," ASHRAE JOURNAL, pp. S31-S34.

449 [18] Larsen. L. F. S., 2006 "Model based control of refrigeration systems." Department of Control Engineering, Aalborg University.

451 [19] Baxter. V. D., 2003, "IEA Annex 26: Advanced supermarket refrigeration/heat recovery systems," ORNL Oak Ridge National Laboratory (US).

453 [20] Tassou. S., Ge. Y., Hadawey. A., and Marriott. D., 2011, "Energy consumption and conservation in food retailing," Applied Thermal Engineering, pp. 147-156. 
455 [21] Coulomb. D., Dupont. J., and Pichard. A., 2015, "The role of refrigeration in the global economy," 29th Informatory Note on Refrigeration Technologies; Technical Report; International Institute of Refrigeration: Paris, France.

[22] Shafiei. S. E., Rasmussen. H., and Stoustrup. J., 2013, "Modeling supermarket refrigeration systems for demand-side management," Energies, pp. 900-920.

[23] Petersen. L. N., Madsen. H., and Heerup. C., 2012, "Eso2 optimization of supermarket refrigeration systems," Technical University of Denmark, Department of Informatics and Mathematical Modeling, Tech. Rep.

[24] Ge. Y., and Tassou. S., 2000, "Mathematical modelling of supermarket refrigeration systems for design, energy prediction and control," Proceedings of the Institution of Mechanical Engineers, Part A: Journal of Power and Energy, pp. 101-114.

[25] Sarabia. D., Capraro. F., Larsen. L. F., and de Prada. C., 2009, "Hybrid NMPC of supermarket display cases," Control Engineering Practice, pp. 428-441.

[26] Larsen. L. F., Izadi-Zamanabadi. R., and Wisniewski. R., 2007, "Supermarket refrigeration

[27] Glavan. M., Gradišar. D., Invitto. S., Humar. I., Juričić. Đ., Pianese. C., and Vrančić. D., 2016, "Cost optimisation of supermarket refrigeration system with hybrid model," Applied Thermal Engineering, pp. 56-66.

[28] Vinther. K., Rasmussen. H., Izadi-Zamanabadi. R., Stoustrup. J., and Alleyne. A. G., 2013, "A learning based precool algorithm for utilization of foodstuff as thermal energy storage," in IEEE International Conference on Control Applications (CCA), pp. 314-321.

[29] Postnikov. A., Albayati. I., Pearson. S., Bingham. C., Bickerton. R., and Zolotas. A., 2019, "Facilitating static firm frequency response with aggregated networks of commercial food refrigeration systems," Applied energy, p. 113357. 
[30] Saleh. I. M., Postnikov. A., Arsene. C., Zolotas. A. C., Bingham. C., Bickerton. R., and Pearson. S., 2018, "Impact of demand side response on a commercial retail refrigeration system,"

[31] Albayati. I. M., Postnikov. A., Pearson. S., Bickerton. R., Zolotas. A., and Bingham. C., 2020, "Power and energy analysis for a commercial retail refrigeration system responding to a static demand side response," International Journal of Electrical Power \& Energy Systems, p. 105645.

[32] Danfoss, "Capacity controller - EKC 531A and 531B 084B8003 / 084B8004," ed, 2003.

[33] Agas. "R407F (Genetron Performax LT)." Agas. (accessed Mar., 2020).

[34] L. Gas. "Industrial Gases - R407A." Linde Gas. (accessed Mar, 2020).

[35] Rac. "Is it time to stop using R404A?" RAC. (accessed Mar, 2020).

[36] R. E. S. Limited, "Model: ZB45KCE-TFD Data," ed. Leicestershire, 2020.

[37] R. E. S. Limited, "Model: ZF09K4E-TFD Data," ed. Leicestershire, 2020.

[38] R. E. S. Limited, "Model: ZF15K4E-TFD Data," ed. Leicestershire, 2020.

[39] Postnikov. A., Zolotas A., Bingham. C., Saleh. I. M., Arsene. C., Pearson. S., and Bickerton. 495

[40] Vinther. K., 2014, "Data-driven control of refrigeration systems," Ph. D. thesis, Videnbasen for Aalborg UniversitetVBN, Aalborg.

[41] Lemmon. E. W., Huber. M. L., and McLinden. M. O., 2013, "NIST reference fluid 501 thermodynamic and transport properties-REFPROP," NIST standard reference database, $\mathrm{p}$.

\section{List of Tables}

505 Table 1: Summary of the system parameters used in the presented model [29, 30] and [36-38].

506 Table 2: Tuned parameters used for the validation of the developed model. 


\section{List of Figures}

508 Figure 1: Typical refrigeration system layout (cited from [18]).

509 Figure 2: Schematic layout of Riseholme Refrigeration Research Centre at (cited form [30]).

510 Figure 3: High temperature (HT) Monza display case used at Riseholme Refrigeration Research Centre.

511 Figure 4: Compressor pack and controller used at the Riseholme Refrigeration Research Centre.

512 Figure 5: First-in first-out (FIFO) compressor operation cycle (cited form [32]).

513 Figure 6: Main subsystems and refrigeration cycle for the refrigeration system.

514 Figure 7: High temperature (HT) display case schematic.

515 Figure 8: Simulation of the HT display temperatures for the developed refrigeration system model.

516 Figure 9: Real operational data for the HT temperatures of the refrigeration system

517 Figure 10: Simulation of the expansion valve operation for the developed refrigeration system model.

518 Figure 11: Real operational data of the expansion valve for the refrigeration system.

519 Figure 12: Simulation of the suction pressure for the high temperature system of the developed

520 refrigeration system model.

521 Figure 13: Suction pressure for the high temperature system at Riseholme Refrigeration Research

522 Centre.

523 Figure 14: Simulation of the of power consumption for the HT compressors of the developed

524 refrigeration system model.

525 Figure 15: Power consumption for the HT compressors at Riseholme Refrigeration Research Centre.

526 Figure 16: Total energy consumption for the HT compressors of the developed refrigeration system 527 model.

528 Figure 17: Total energy consumption for the HT compressors at Riseholme Refrigeration Research 529 Centre. 